\title{
Case Study: \\ The Emerald Industry In Colombia
}

Carlos Miguel Barber Kuri, Universidad Anáhuac México Sur, Mexico

Karla Rosa Dávila Ramírez, Universidad Anáhuac México Sur, Mexico

\begin{abstract}
This case study was written using different sources which are mentioned trough the document. This synthesis of information is oriented to academic aims. This document was translated from the original one by Carlos Miguel Ramos Salazar on September, 2006
\end{abstract}

\section{INTRODUCTION}

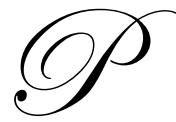

recious stones are one of the most valued objects in the history of the human being.

Among the loveliest gems that we can find are emeralds with their gorgeous green colour; it is also their shade which determines the price of them and it can be multiplied if the colour is intense, because it gives an spectacular view to the jewel where is placed the emerald.

The hardness of emeralds is another special characteristic in the market of gems.

Colombia is one of the richest countries in the production and exploitation of emeralds. In fact, Colombia produces more than $80 \%$ of the worlds production; according to the information of the Colombian Embassy in Tokyo, Japan.

Colombian citizens have extracted this natural price since some centuries ago; unfortunately their production processes haven't been so competitive to export processed emeralds; but now, the Colombian Government tries to erase all these mistakes and search more competition in the jewel market.

World market is now declining, the gold époque of emeralds has passed to the history and actual prices are lower than those that Colombians used to have. A few years ago, the mining social class was one of the most benefited, in economic terms.

\section{INFORMATION ABOUT COLOMBIA}

Colombia is a Latin American country, limited by South American and Central American countries, like: Peru, Venezuela, Brazil and Equator in South America and Panama in Central America. Their beaches are surrounded by the Pacific Ocean and the Caribbean Sea in the North East border.

Colombia has tropical weather through the coast and in the low territories it's colder than in the high zones. The highest zone is the Pico de Cristóbal Colón, placed at 5775 meters high. This is a fortunate country because it is the only one with coasts on both oceans, Pacific and Atlantic.

Colombia is rich in natural resources. Among the most important are petroleum, natural gas, iron, nickel, gold, coal, copper, emeralds and hydroelectric energy. The most important industries are: Textiles, processed food, oil, clothing, shoes, chemical products, cement and the processing of natural resources like gold, copper, emeralds and coal. 
It's important to say that Colombia is the second country in biodiversity all around the world; the fourth in water resources, with a gorgeous national anthem; it has also the record of the longest anaconda, the best coffee in the world and the first exporter of emeralds.

\section{SCHEME 1: INFORMATION ABOUT COLOMBIA, 2004 AND $2005^{1}$}

\begin{tabular}{|c|c|}
\hline Capital & Bogotá \\
\hline Surface & $1,138,910$ square kilometres \\
\hline Population & $42,954,279$ persons \\
\hline Official Language & Spanish \\
\hline Official Currency & Peso Colombiano (COP) ${ }^{2}$ \\
\hline Pib Percápita & 6,600 USD \\
\hline Pib Growth & $3.6 \%$ \\
\hline Unemployement & $13.6 \%$ \\
\hline Exportations & \$15.5 million dollars \\
\hline Importations & \$15.34 million dollars \\
\hline Religions & A0\% catholic-roman and 10\% others \\
\hline Executive Head & Álvaro Uribe Velez since August 7, 2002. \\
\hline
\end{tabular}

\section{HISTORY OF COLOMBIA}

Colombia is definitely a rich country in history. Its first colonial cities, as we know them now, were build 400 years ago, p.g. Cartagena, which was founded in 1533 by Don Pedro de Heredia, three years later, Cali was founded and in 1589 Bogota City.

The Constitution of the Federation of United Provinces of New Granada was written in 1811 which was used by the Congress to create Cundinamarca. The next years represented the golden époque of this country.

In 1819, is formed the Gran Colombia, integrated by Cundinamarca, Venezuela and Equator, some years latter, Panama joined this group. In 1830 Equator and Venezuela took their independence and the Gran Colombia is only integrated by Panama and Colombia.

In 1861, a new Constitution was written, creating the United States of Colombia. In 1884, during the government of Rafael Núñez, is created a united constitution, once independent Panama, and the territory was named as we actually know, the Republic of Colombia

In order to govern this country, parties from right and left made a pact of alternated rotation of power, but it was cancelled in 1970.

Colombia is one of the countries that has been involved in guerrillas inside its territory. Some presidents have tried to pacify these movements, but without successful results.

In 1983 Colombia takes place in international markets thanks to its importation substitute policy and the growth of exportations; also because of the Law of Foreign Commerce. ${ }^{3}$

${ }^{1}$ Cf. "Colombia" The CIA World Fact Book (2005) http://www.cia.gov/cia/publications/factbook/geos/br.html (October 25, 2005)

${ }^{2}$ A Colombian peso is equivalent to 0.000436453 USD. (October 28, 2005) Source: Universal Currency Converter XE. com. from yahoo.com. 


\section{WHAT IS AN EMERALD?}

The World emerald comes from the Latin word smaragdus that signifies green.

Emeralds are from the family of beryl, some siliceous minerals; this family also includes some stones like, wide blue aquamarines, golden heliodors, red beryl, green beryl, etc.

An emerald is a variety of precious stones, characterized by its green and transparent colours. Green colour is because of the chrome oxide ${ }^{4}$, nevertheless its colour depends on minerals inside the stone that affect its purity.

Emeralds are formed by aluminium silicate, beryl and glassine and characterized by its singular hardness, they are harder than quartz.

An emerald has a gem quality and its beauty has been part of the human being since some centuries ago. Emeralds of ancient times were prized by its colour. Most ancient emeralds, principally from Egypt, where were first exploited since the XIX century, had pale and small. Crystals were from South America, principally from Colombia, but there were also great quality gems from the Ural Mountains in Russia and from North Carolina in the United States. ${ }^{5}$ Actually we find emeralds in Brazil, Pakistan, Afganistan, Madagascar, Nigeria, Zambia, and Zimbabwe.

The information about the temperature of the gem, pressure, identity, fluids, physic environment and other general characteristics can be obtained from some mineral crystals that form the Mother gem, nevertheless they are not part of them, they are different.

Emeralds acquired the stone category in August 1912, when the Retail Jeweller's Association of America published a list of selected gems by this association. This process has been changed and in 1938 the American Gem Society adopted this list as criteria. Since the first publication the list, there have been some changes, but emeralds still are considered as precious stones.

\section{COLOMBIAN EMERALDS}

"The $80 \%$ of the most precious stones in the world comes from Colombia". ${ }^{6}$

The particular beauty of Colombian emeralds is because of their intense brilliance and their size; in most of the cases, the volume are from eight to ten karat. The best way to measure emeralds weight is with karats, equivalent to 0,20 grams or $0,02380 \mathrm{oz}$.

People that study gems are able to recognize an emerald from Colombia due to their shape and small particles inside of them and they are almost invisible for inexpert persons.

The normal environment that forms an emerald is a metamorphic igneous ambiance, that is, in high temperatures. In Colombia the process is different. Colombian emeralds have their origin in a sedimentary ambiance, that is, with low temperatures. The elements that integrate emeralds must have contact with rim origins which have been in contact with high temperatures.

\footnotetext{
${ }^{3}$ Cf. Pedraza Hermes Rincón, Omar. Colombia II, Resources and regions. REI-MÉXICO. México 1990

${ }^{4}$ European-American Universal Encyclopedia. Ed. Espasa Calpe S.A.. Tomo 3. España. 2003 Pp. 1732-2636 Consulted page 2498

${ }^{5}$ Cf. Encyclopedic Dictionary Espasa. Segunda Edición. Ed. Espasa Calpe S.A. Tomo VIII. 1992. Madrid, España 1992. Pp 4192-4798 Consulted page 4606

${ }^{6}$ Montenegro, Gustavo Adolfo. Revista D Mundo. Article: Seminar of Free Publication No. 50. Publisher on June 19, 2005 (October 25, 2005)
} 
Colombian emeralds can be distinguished by three factors. First, is colour, emeralds can have a dark green, blue or yellow, it depends on the characteristics and the type of the ground where they were found. Second, is the shape, depending of the mine, they will have different shapes. Third, is the way of extraction; if they were extracted using powder or other explosives; the gem will present some fractures in the surface and also inside them. That's why Colombian emerald are extracted using picks, shovels and big pick machines in deep excavations to avoid fractures and get emeralds with best quality.

\section{HISTORY OF EMERALDS}

In ancient times, emeralds were only a prize for distinguished kings and queens, to pharaohs and tsars. Cleopatra loved her emeralds, their origin was unknown until the XIX century, when mines were founded near the Red Sea.

In the Ancient Rome, Neron loved his emeralds and asked the elaboration of glasses made with emeralds in order to have a better view of gladiators in the Roman Coliseum, admiring the beauty of emeralds and protecting from the sun.

In America, especially in Colombia, history of emeralds is different. Ethnic people from the north territory, that now we know as Bogota, had an excellent knowledge of how to extract the stones; nevertheless, they were never interested on developing process to polish the emeralds. But since the arrival of Cristobal Colon and other Spanish conquerors, process changed.

In the first years of the XVII Century, ethnic civilizations were an obstacle for Spanish peoples who wanted to get these precious stones; nevertheless, until actual times, natives named guaqueros, doesn't want other persons to exploit their mines, in fact they're risking their life in the extraction processes of stones and don't recognize the common right to let everyone to get this type of gems.

Technical exploitation of emeralds in Colombia started on 1930, when machines arrived to this country; these machines were useful to make tunnels and extractions. The commerce of emeralds has been named "green spell".

\section{DEPOSIT OF EMERALDS IN COLOMBIA}

Colombia is one of the richest countries on emerald production.

"Every deposit of emeralds in Colombia are placed in the Oriental Cordillera in two important strips named Oriental and Occidental Emerald Belts. The mines of emeralds that are actually exploited in these strips are inside the limits of the municipalities Boyacá and Cundinamarca"7.

Some of the municipalities where it's possible to find emeralds are Vélez, Bolívar, Guavatá, Muzo, PeñasBlancas and Cosquez; their emeralds are geologically similar to those of the zone of Cundinamarca. In this place, there are different municipalities with minimal production, and they are Yacopi and Peña; Otanche is other producer municipality of emeralds. In 2003, exports from this municipality were of 4 million and 167 thousand dollars, equivalent to 33 thousand karats of polished emerald.

Between the most important mines of emeralds are: La Pita, la Mina, Muzo and 19 areas in the zone of Muzo-Polveros.

Department of Bocayá, in there, enormous emeralds are extracted, they are also hard and crystalline.

\footnotetext{
${ }^{7}$ http://www.colciencias.gov.co/agenda/pdfs/pn_58.pdf

(October 28, 2005). Three research projects, kaolin, emeralds and jewels
} 
The golden époque of emerald production was between the 70's and 80's.

\section{THE MINE OF MUZO}

Actually, almost every mine of emeralds are property of the State, it remains only one mine independent. The mine of Muzo is held by private investors; as well as foreigners that have obtained the allowance to exploit the mine for around 10 years. Between the exploited areas, there is the primary deposit of Muzo.

The permission of exploitation was until 2004, an enterprise named Tecminas, has a policy of low salaries, approximately 600 Colombian pesos by month. Indeed, workers must live into a military camp, because of the presence of dangerous thieves and military patrols.

In spite of all of this insecurity in the mine, lots of Colombian citizens accepted this labour, because once finished the extraction, the administration of Tecminas selected the biggest emeralds and the rest could be conserved by workers.

Residues from extraction, including the slag that cover the emeralds are thrown down river, where is established an important population of guaqueros who pick them up to search some possible remains of emeralds. In average, 4 or 5 guaqueros died because of conflicts about emeralds. ${ }^{8}$

\section{EXPORTS OF EMERALDS}

It's not easy to quantify the production of emeralds, because some variation of colours can raise the prices. ${ }^{9}$

Colombia has been characterized by his exports of emeralds "without process", indeed without any type of polish process which gets down their added value. International market has some problems with the production of the stone because a low rate of prices, that's why the Colombian Government is taking some actions.

“According to Daniel de Narváes, president of the Association of Emerald Producers of Colombia, in 1995, Colombia exported 452 million dollars in emeralds; in 2002 it got down to 89,3 million dollars and in 2003 there were only 79,1 million dollars; maybe in some years we'll need to import emeralds, he said" ${ }^{10}$

Since 2003, the President Alvaro Uribe Vélez desired to give a change to this industry and focus on exports of precious stone with an added valued when they were polished and refined. To reach these objectives it was necessary to create the Centre of Technological Development (CDT) markets.

San Pablo de Borbur is the most important municipality of production of emeralds for international

\footnotetext{
${ }^{8} \mathrm{Cf}$.http://www.cartagenainfo.com/Joyerias/mines.html (October 28, 2005) Colombian mines: Temprano \& Corriente.

${ }^{9}$ Cf. Montenegro, Gustavo Adolfo. Review D Mundo. Artícle. Seminar of Free Publication No. 50. Publisher on June 19, 2005 (October 28, 2005)

${ }^{10}$ Rf.http://www.presidencia.gov.co/sne/2004/junio/07/16072004.htm (October 28, 2005) Oficial website of the Colombian government. Publication of the Casa de

Nariño, President of the Colombian Republic (June 7, 2004) Uribe claims an acceleration to the Emerald Development Centre.
} 


\section{SCHEME 2: EXPORTS OF EMERALDS ${ }^{11}$}

\begin{tabular}{|c|c|}
\hline Year & Exports \\
\hline 1993 & 401.4 \\
\hline 1994 & 423.1 \\
\hline 1995 & 452.4 \\
\hline 1996 & 174.7 \\
\hline 1997 & 141.4 \\
\hline
\end{tabular}

SCHEME 3: EXPORTS OF EMERALDS IN COLOMBIA BY MUNICIPALITY ${ }^{12}$

\begin{tabular}{|c|c|}
\hline Municipality & Porcentage \\
\hline San Pablo De Borbur & $67 \%$ \\
\hline Muzo & $10 \%$ \\
\hline Coscuez & $7 \%$ \\
\hline Pauna & $5 \%$ \\
\hline Otanche & $3 \%$ \\
\hline Quipama & $3 \%$ \\
\hline Maripi & $2 \%$ \\
\hline Otros & $3 \%$ \\
\hline
\end{tabular}

In 1995 the registered incomes from exports were of 456 million dollars. In 2004 sales to the international market were of 75 million dollars. Between January and September 2005, the exports registered were around 58 million dollars. The actual situation of low Colombian exports is due to some reasons. First, the deposits of emeralds in Boyacá and Cundinamarca are getting depleted; also social problems all around the country have stopped the plans of a great amount of foreign investors. ${ }^{13}$

Principal destinations of exports of these precious stones are: The United Status, Switzerland, Japan, Belgium, Spain and Hong Kong.

Japan and

2004 was "The Year of the Colombian Emerald". This campaign made by the Association of Jewellers of The firm.

Tasaki Shinju, was really important to promote the gem; as emeralds as well as the jewels made with these precious stones. In fact, Colombian exports to Japan rose in $9,6 \%$, which helped to reanimate the hope of Colombian citizens to their emeralds. ${ }^{14}$

2006 represents great opportunities for producers, due to the project of making a specialized laboratory on emeralds from Colombia; this laboratory will start giving international certificates that will allow a better position in the market. It is also pretended that the State and mine enterprises work together to increase the production of emeralds.

\footnotetext{
${ }^{11}$ Planning and Publication National Department of the Information Centre and Managerial Information about Iberian America (CIDEIBER)

${ }^{12}$ El Universal. Caracas. May 14, 2002. Annual Bulletin Energetic and Mines. No 29. Publisher on April 2002

${ }^{13}$ Review Cambio. Low karate Colombian emeralds have hade a decline of production, stones lost value and revaluation. Published on October 10, 2005

${ }^{14} \mathrm{Cf} . \mathrm{http} / / /$ www.japonenespanol.com/Colombia/200407-colom.htm (October 7, 2005) Japan in spanish. More for the Colombian emerald.
} 


\section{GRAPHIC 1: COLOMBIAN EXPORTS OF EMERALDS ${ }^{15}$}

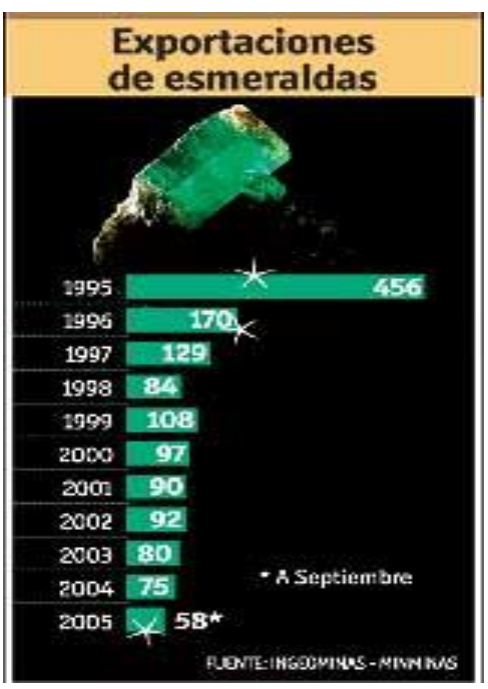

\section{INTERNATIONAL PRODUCTION OF EMERALDS}

Emeralds have suffered a low rate of international production, because a lot of foreign producers are discouraged because of the low prices of emeralds on market.

Colombia offers to the world $60 \%$ of the total amount of emeralds; international competence, talking about production, Colombia is in the first place; nevertheless, there are other countries that must be considered due to their volume of extractions.

\section{SHEME 4: INTERNATIONAL PRODUCTION OF EMERALDS ${ }^{16}$}

\begin{tabular}{|c|c|}
\hline Country & Production $^{\mathbf{1 7}}$ \\
\hline \hline Zambia & $15 \%$ \\
\hline Brazil & $10 \%$ \\
\hline Madagascar & $3 \%$ \\
\hline Zimbabwe & $2 \%$ \\
\hline Afganistan & $2 \%$ \\
\hline Pakistan & $2 \%$ \\
\hline
\end{tabular}

\section{PINK EMERALDS}

Since St Valentine's Day of 2003 (February 14), emeralds with pink colour officially acquired the category of precious stones.

\footnotetext{
15 Ídem

${ }^{16}$ Rf Londoño Ramírez, Jorge Enrique http://www.jecultura.com/muzoturistico/cultura/expedicion\%20verde/ (October 7, 2005) Green expedition.

${ }^{17}$ Observ. Information in percentage have been obtained from the world population.
} 
The Pink Emerald Company, LLC, launched to the public in general "The Collection Think in Pink". This company has been established as the principal distributor of pink emeralds all around the world; in fact, the collection, that was unknown by most of the public until a few years, includes some valued emeralds because of their size and their intense pink colour, which raises the price. The most expensive pink emerald with a shape of a heart, was found in Minas Gerais in Brazil, with a cost of 1,5 million dollars; it is know as "The little pink heart".

"These delicate and precious natural prizes are 25000 times more difficult to find than green emeralds; 40000 times more difficult to find than zephyrs and more than 120000 times more difficult to find than diamonds. There is approximately one pink emerald between 175000 processed diamonds. The principal factor that contributes to this lack of pink emeralds is that actually there is any place on Earth that produces pink emeralds."18

\section{ISSUES}

- International demand is decreasing as well as prices and the value of the stone, some reasons of the low rates of exports. We went from 89,3 million dollars in 2002 to 79,1 million dollars in 2003.

- $\quad$ The price of the necessary explosives used in extraction is really high. ${ }^{19}$

- $\quad$ There are a lot of social issues about the mine industry; specially some problems different to health topics related to the extraction process of gems, indeed, sanitary resources are not considered to guarantee the health of mine workers. Also, mines are placed in mountain zones; which makes difficult the access of medical attention.

- Due to the control form the State on production, lots of times, gems gets into the market by unknown ways and without the authorization from the State, that's why Colombia is considered as one of the best emerald producers with the best registry of exports.

- $\quad$ Land workers and labourers of mines live around the mines. In the night, mines are the objective of people who dig wholes searching to find some emeralds; that's why "celadores" were born, they are persons that ride horses with the permission to shut every people found in front of them.

- $\quad$ The Green War, was named by Colombian people when violence caused the death of Efraín González, which had the nickname of the Colombian Robin Hood. In the municipalities of Chiquinquirá, Muzo, Coscuez, Borbur and Somondoco, 1200 deaths were registered. Due to this situation of insecurity, the government decided to close the mines of emeralds in 1971 and let them in charge of the police. The Green War started as a result of politic conflicts related with the "mafia" of the extraction of emeralds. ${ }^{20}$

\footnotetext{
${ }^{18}$ Rf.http://www.prnewswire.co.uk/cgi/news/release?id=96614

(October 7, 2005) Pink emerald relieves in precious stone on St. Valentine's Day in 2003.News Release. Publshed on January 20, 2003 and distributed by PR Newswire on behalf of The Pink Emerald Company, LLC

${ }^{19} \mathrm{Cf}$. http://www.presidencia.gov.co/sne/2004/junio/07/16072004.htm (October 28, 2005) Official website of the Colombian government. Publication of the Casa de Nariño,Precidency of the Colombian Republic (June 7, 2004) Uribe claims to accelerate a Development Centre of Emerald.

${ }^{20} \mathrm{Cf}$.http://www.derechos.org/nizkor/colombia/libros/jinetes/cap1.html (October 7, 2005) The Riders of Cocaine
} 